YEARBOOK of ANTITRUST and REGULATORY STUDIES www.yars.wz.uw.edu.pl
Peer-reviewed scientific periodical, focusing on legal and economic issues of antitrust and regulation. Creative Commons Attribution-No Derivative Works 3.0 Poland License.

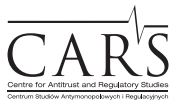

Centre for Antitrust and Regulatory Studies, University of Warsaw, Faculty of Management www.cars.wZ.uw.edu.pl

\title{
Information Exchange Going Digital - Challenges to Hungarian Competition Law Enforcement
}

by

\author{
Judit Firniksz and Borbála Dömötörfy*
}

\section{CONTENTS}

I. Introducton

II. Information exchange

III. Assesment of information exchange

IV. Risk factors of information exchange

1. Traditional risk factors of restrictive effects

2. New risk factors and policy challenges in the assessment of information exchange

V. Information exchange in recent Hungarian case law

1. The Contact Lenses Case

1.1. Assessment of horizontal information exchange

1.2. Role of the intermediary

1.3. Final decision of the Hungarian Curia

2. The BankData Case

2.1. Another infringement decision based on potential effects

2.2. Liability of intermediaries

3. The Meat Products RPM Case

3.1. A market research company in the focus again

VI. Recent Hungarian experiences: challenges to the enforcement

1. Role of extended economic and IT-related argumentation in the evidence

* Judit Firniksz - dr.iur, MSc, PhD candidate at the Faculty of Law at Pázmány Péter Catholic University, senior attorney at Réti, Várszegi and Partners Law Firm PwCLegal, judit.firniksz@pwc.com. Borbála Dömötörfy - dr.iur, LLM, PhD candidate at the Faculty of Law at Pázmány Péter Catholic University, attorney at Réti, Várszegi and Partners Law Firm PwCLegal; e-mail: borbala.domotorfy@pwc.com. The authors would like to thank their former colleague, Peter Mezei, for his valuable contribution. Article received: 2 June 2019, accepted 10 September 2019. 
2. Presence of 'secondary' intermediaries

3. Costs of information exchange

4. Age of the data

VII. Demand-side initiatives of GVH

1. Demand-side effects of digital economy

2. Digital Consumer Strategy

VIII. Conclusions

\section{Abstract}

The aim of the paper is to present an insight into the challenges raised by digitalized and data-driven markets to competition policy and enforcement in the Big Data era. Focusing on the assessment of information exchange in the digitalized environment, traditional risk factors are analyized and it is argued that new risk factors can be identified. The paper provides an overview of relevant recent Hungarian case-law to examine the role of information exchange, taking place in a data environment that offers an increased amount of up-to-date and relevant market information for analysis. Further, the paper summarizes the enforcement responses to the demandside challenges raised by online platforms, user interfaces applying new approaches and practices that can directly influence consumer behavior. The consequence is drawn that the extended economic and IT-related argumentation may affect the nature of proceedings and some new phenomena, as the role of secondary intermediaries, integration of online and offline market segments open new fields for assessment.

\section{Resumé}

Lobjectif de cet article est de donner un aperçu des défis posés par les marchés de la numérisation et des données à la politique de la concurrence et à son application à l'ère des grandes données. En se concentrant sur l'évaluation de l'échange d'information dans l'environnement numérique, les facteurs de risque traditionnels sont analysés et on fait valoir que de nouveaux facteurs de risque peuvent être identifiés. Le texte donne un aperçu de la jurisprudence hongroise récente en la matière afin d'examiner le rôle de l'échange d'informations dans un environnement de données qui offre une quantité accrue d'informations actualisées et pertinentes sur le marché à analyser. En outre, l'article résume les mesures d'application de la loi prises pour relever les défis posés par les plateformes en ligne, dont les interfaces utilisateur appliquent de nouvelles approches et pratiques qui peuvent influencer directement le comportement des consommateurs. La conséquence en est que l'argumentation économique et informatique peut affecter la nature des procédures et certains phénomènes nouveaux, comme le rôle des intermédiaires secondaires, l'intégration des segments de marché en ligne et hors ligne ouvrant de nouveaux domaines d'évaluation. 
Key words: competition law; information exchange; algorithms; big data; digital markets; Hungarian Competition Authority, enforcement

JEL: K21

\section{Introduction}

Datafication, digitalization, data-driven markets, online platforms, digital economy; practically, these expressions are used in every segment of the economy, signalling that data defines the rapidly changing economic landscape, digital technologies are diffused in business processes. As a result, use of datadriven toolsets has a deep impact on the performance of firms. Digitalization of the value chain is reshaping the processes from the development of products through production, logistics and sales systems to their acquisition by end users. Product digitalization is creating new markets and is fundamentally changing data-driven business models, which are simultaneously generating new organizational structures, working methods. These parallel processes result in new channels and context in the communication with buyers, consumers, customers, clients, users and employees (Preta and Maggiolino, 2018). Some digital tools, such as software-based algorithms ${ }^{1}$, enormous structured and unstructured databases, and access to Big Data play a key role in improving pricing models, providing products and services tailored to consumers, and predicting market tendencies. Data-driven markets may offer benefits both on the supply side by increasing transparency and enhancing the number and quality of the products available, and on the demand side by assisting consumers with sorting out the relevant information. Digitalization has obvious benefits affecting each sector of the economy, however, new methods of collecting and analyzing data also raise competition law concerns on the grounds that data acts in the digitalized markets as a new factor determining market power and market transparency. Algorithms can be displayed and implemented in a variety of ways, with human and machine execution, but a new peak was reached with computer science. Software-based algorithms have prepared the ground for highly complex data processing and data evaluation processes, with whose efficiency the human mind cannot compete. Developments in artificial

${ }^{1}$ In accordance with the set of definitions and concepts adopted by OECD (2017) we also accept the formal and precise definition of algorithm formulated by Wilson, R.A. and Keil, F.C. in 1999 (The MIT Encyclopedia of the Cognitive Sciences, MIT Press): 'An algorithm is an unambigous, precise, list of simple operations applied mechanically and systematically to a set of tokens or objects. The initial state of the token is the input; the final state is the output.' 
intelligence and machine-learning have also led to algorithms for decisionmaking and prediction (OECD, 2017).

Wide availability and analyses of data have always increased market transparency, and transparency may entail positive effects to consumers by improving the comparability of products and services. By this, information asymmetry is reduced and as a result, competition may intensify. As a novel phenomenon in online economic processes, consumers (for various purposes and on a wide variety of online platforms) provide a wide range of data, and (i) Big Data analysis methods make it possible to track consumer habits and interests, enabling personalised direct access to consumers; (ii) user data as input becomes an important asset of platform operators. Direct access to consumers and transparency of information about consumer behavior may increase the chances of new entrants, while at the same time expose consumers to new market practices, enhancing their vulnerability to some extent.

Competition law meets challenges in many fields, recent Hungarian case-law and policy-making have been also faced with the changes in the information environment of decisions taken by companies and consumers. In our paper, through the legal prism of Hungarian competition law enforcement, we will look at two key characteristics of digital economy from the practitioners'perspective: (i) information exchange taking place in a data environment that offers an amount of fresh and relevant market information for analysis, which would have been unimaginable in the past; (ii) online platforms, user interfaces applying new approaches and practices (for example, algorithm-based decision-making) that can directly influence consumer behavior.

\section{Information exchange}

Big Data is not only a significantly increased amount of accessable data made available in the online world via digital technologies; the concept of Big Data cannot be examined independently from data analysis tools used to process such data. How data is used, collected, and the difference between modern and traditional ways of processing are key elements of the definition of Big Data, just as the three V's - velocity, variety and volume - are. ICO lists the use of algorithms, the opacity of the processing, the tendency to collect 'all the data', the repurposing of data, and the use of new data types as distinctive aspects of data analytics (ICO, 2017).

Indeed, the increased amount of data available on the market is not sufficient to reach a high degree of market transparency, its combination with the ability to collect and process data provided by the algorithms allows market players to compare online information. 
Market transparency, however, is not the only factor to be taken into account when evaluating the market environment of information exchange. Beyond transparency, in terms of market characteristics, concentration, stability, symmetry, complexity and balance of the relevant market are also traditional risk factors. Before analyzing such market characteristics, we must, however, first integrate information exchange into the nomenclature of behaviors relevant from a competition law point of view.

\section{Assessment of information exchange}

Any information exchange that enables a company to become aware of the future market strategy of its competitor may eliminate the uncertainty that is an inevitable element of competitive behavior. As a consequence, coordination may replace competition.

The economic theory behind the rules of competition law builds on game theory to a significant extent. The basic model which could be used to explain the prohibition of information exchange between competitors is the general form of the Prisoner's Dilemma. Two suspects, A and B, are arrested for a crime, but here is little evidence supporting their accusation, so the prosecutor decides to separate the two suspects and privately proposes to each of them the following: the suspect confessing the crime will get a reduced sentence of 1 year, provided that the other suspect stays silent; while in this case the other suspect will get 10 years. If they both confess, each will get 3-3 years. Finally, if both suspects stay silent, each will get 2-2 years.

Table 1. General model of the prisoner's dilemma

\begin{tabular}{|c|l|c|c|}
\cline { 3 - 4 } \multicolumn{2}{c|}{} & \multicolumn{2}{c|}{ A } \\
\cline { 3 - 4 } B & Confess & Silent \\
\hline \multirow{2}{*}{ Confess } & $3 / 3$ & $10 / 1$ \\
\cline { 2 - 4 } & Silent & $1 / 10$ & $2 / 2$ \\
\hline
\end{tabular}

Source: Authors' own work based on general models (see e.g. Nicholson and Snyder, 2010, p. 180).

In the case of this basic model of the Prisoner's Dilemma, the dominant strategy - the best response to any strategy played by the other suspect - of each suspect is to confess, however, a better outcome would arise for each of them if both stay silent. For an outcome to be a Nash equilibrium, both players must be playing a best response to each other; therefore, both suspects 
confessing is the Nash equilibrium of the game. Obviously, there would be a better outcome for both suspects than the Nash equilibrium of the game by both staying silent - but it is not stable, each suspect would prefer to deviate spending one year in prison against two (Nicholson and Snyder, 2010).

But how does the Prisoner's Dilemma relate to information exchange? Since the prosecutor approaches the suspects separately, they cannot communicate; in the general form of the Prisoner's Dilemma, it is a prerequisite that no communication takes place between the suspects. Communication between the suspects would influence the outcome of the game by increasing the likelihood of cooperation, especially if communication relates to future actions, the exchange of information is repetitive ${ }^{2}$ and credible (Rosenfield, Carlton and Gartner, 1997). The above listed three characteristics of communication or signalling are enhanced in the Big Data environment by its very nature. Ezrachi highlights that information exchange on digital markets is likely to take place even tacitly, that is, without active communication (Ezrachi, 2018). Therefore, digitalization and the Big Data environment diminish at least one important prerequisite of the simple form of Prisoner's Dilemma, and increases the likelihood of the cooperative outcome. Since competition destroys profit (Thiel, 2014), it is a rational company's interest to use digitalization and Big Data in a way to reach the cooperative outcome.

The Hungarian Competition Act $^{3}$ (in accordance with Article 101 of TFEU) does not include information exchange performed by competitors in the examples listed as restrictive agreements or concerted practices, therefore, such behaviors must be assessed by applying the general rules. The interpretation of the term 'information exchange' depends on the context and information exchange systems that can be divided into the following major categories: (i) information exchanges that constitute part of 'classical' (for example, horizontal price fixing) cartel agreements ${ }^{4}$; (ii) information exchanges that are linked to legitimate cooperation agreeements or mergers, (iii) 'stand alone' information exchanges without any underlying (anti-competitive or legitimate) agreements (Fejes, 2016).

2 The number of repetitions of the game and repetitions of comumnication are different features. The number of repetitions of the game also has significant impact on the outcome of the game - if the game is repeated indefinite times, the number of repetitions increases the likelihood of cooperation by definition (Nicholson and Snyder, 2010), the article refers here to repetition of communication.

3 A tisztességtelen piaci magatartás és a versenykorlátozás tilalmáról szól 1996. évi LVII. törvény - Act LVII of 1996 on the Prohibition of Unfair and Restrictive Market Practices. Rretrieved from http://www.gvh.hu/en/data/cms1033354/Hungarian_Competition_Act_20150901_. pdf (30.07.2019).

${ }^{4}$ An information exchange that is necessary for the implementation or monitoring of an existing cartel is, as a principle, to be assessed together with and in the context of the underlying agreement. 
As standard consecutive logical steps of the general rules, both under Hungarian and under EU jurisprudence, the following questions must be assessed: (i) is there any agreement between undertakings, decision taken by an association of undertakings or concerted practice; (ii) is the information exchange considered a restriction by object or a restriction by effect/ potential effect; (iii) does any exemption apply.

The existence of an agreement can be proved in most organized data exchanges, the participating companies usually enter into a contract with at least the intermediary (market researcher, consultant) and thus know which other companies participate in the information exchange, that is, which companies can access the data after some processing (Fejes, 2016).

By its very nature, a concerted practice does not contain every element of an agreement. Usually, it is performed in an ad-hoc manner, but it may be apt to coordinate the participants' behavior and by this, it may exclude or significantly reduce competitive risks. The participation of an undertaking in a meeting where the participating undertakings communicate information about their future market behavior is considered a concerted practice, since the information communicated to competitors is presumed to be necessarily taken into account when defining their market behavior. In addition, when shaping their own market behavior, the participants are also assumed to take (directly or indirectly) the information provided by the competitors into account (so-called 'Anic presumption'5). In the case of behaviors that may be included in the conceptual framework of concerted practices, the intent of the undertakings and the existence or possibility of the deliberate restriction of competition has a decisive role.

Depending on the intent of the participants and market conditions, coordination can take multiple forms, it can be explicit, tacit or a combination of the two. Tacit collusion can arise when firms repeatedly take part in market interactions and their behavior is characterized by a conscious parallelism that enables the participants to reach a non-competitive equilibrium on the market. In tacit collusion, there is no need for an explicit expression of intent, if the competitors can recognise their mutual interdependence and maintain their coordination solely on the basis of information available on the market. ${ }^{6}$ Tacit collusion traditionally has rather been assessed in collective dominance cases. The underlying feature in the case of tacit collusion is oligopolistic interdependence, rather that agreement (Simon, 2012). Ezrachi and Stucke

5 Judgment of 8 July 1999, Case C-49/92 P Anic v. Commission, ECLI:EU:C:1999:356, para 121.

6 Tacit collusion arises typically in transparent markets with a limited number of competitors, where the firms can create a non-competitive profit-maximising equilibrium without entering into any direct relationship with each other (OECD, 2017). 
(2018) recommend to apply a distinct approach towards human and algorithmic tacit collusion in the age of digitalization and Big Data. However, this type of evaluation of algorithmic tacit collusion is closer to the category of anticompetitive agreements.

Agreements can restrict competition by their object or effect. The topic of 'by object' restrictions exceeds the scope of our study but the various and complex market effects (simultaneous efficiency gains and competitive constraints) that can be achieved through information exchange limit the scope of the behaviours to which a clear 'by object' concept could be attributed. The Horizontal Guidelines ${ }^{7}$ and the Commission's 'By Object' Guidance to the De Minimis Notice 8 point out that an information exchange between competitors of individualized data regarding the intended future prices or quantities are considered a restriction by object. ${ }^{9}$ Information exchange on future prices and quantities (such as planned future sales, market shares, market areas and consumer groups) may allow competitors to reach a higher price level jointly, without having to face a need to keep up with the price war, and thus, it is particularly likely to lead to collusion.

\section{Risk factors of information exchange}

\section{Traditional risk factors of restrictive effects}

The Horizontal Guidelines describe the method by which the restrictive effects of information exchanges should traditionally be examined on a caseby-case basis, considering all the relevant facts and circumstances of the given case.

For an information exchange to have restrictive effects on competition, it must be prone to have a significant adverse impact on one (or several) of the parameters of competition such as price, output, product quality, product

${ }^{7}$ Communication from the Commission - Guidelines on the applicability of Article 101 of the Treaty on the Functioning of the European Union to horizontal co-operation agreements, OJ C 11, 14.1.2011, p. 1-72.

8 Commission Staff Working Document - Guidance on restrictions of competition 'by object' for the purpose of defining which agreements may benefit from the De Minimis Notice - C(2014) 4136 final. Retrieved from http://ec.europa.eu/competition/antitrust/ legislation/de_minimis_notice_annex.pdf (30.07.2019).

9 Where information exchange is performed as a part of the implementation or monitoring of an existing cartel, it will be assessed as a part of the concerned cartel behavior irrespecitve of whether it covers current/past or future prices or quantities. - 'By Object' Guidance to the De Minimis Notice, para. 2.6 
variety or innovation. The competitive outcome of an information exchange depends (i) on the characteristics of the market in which it takes place, (ii) the nature of the products affected by the information exchange, (iii) the type of information that is exchanged, which may modify the relevant market environment in favor of those who participate in the coordination. Further, it is a key issue that the sustainability of the collusion requires advanced data processing that allow the participants to monitor and enforce the collusion (that is, to detect and retaliate deviant firms).

It is a highly obvious fact that the probability of a collusive outcome is higher in the markets of not too complex products where transparency reaches a significant degree, the number of the market players and their market shares represent a concentrated structure; market players are present on the long run and they are homogenous in terms of most of the relevant parameters (as costs, demand, product range, capacities, size, etc.)

As for the characteristics of the data subject to exchange between the competitors, the strategic nature of the information, its market coverage, its aggregate or individual nature, its age, the frequency of information exchanges, the publicity of the information and information exchanges are as follows:

Information is considered strategic if it is suitable for reducing strategic uncertainty in the market, thus strategic information is mostly based on data on prices (such as actual prices, discounts, price increases or price reductions) and quantities.

To exert an anti-competitive effect by an information exchange, the undertakings concerned should cover a sufficiently large part of the relevant market, since, in the absence of such information, non-participating undertakings would be able to prevent the behavior resulting in restrictive effects on competition. Exchanging aggregated data is less likely to lead to a restriction of competition because from such data any specific information is difficult to recognize. In fact, collection and disclosure of such information by market research firms can be of particular benefit to both suppliers and consumers, as they allow more effective strategy development by securing sectorial benchmarks.

As for data age, there is no clearcut threshold. Generally, the potiental of the data to realize deviation determines if the data can be considered a source of a collusive outcome. Historical data does not enable market players to detect deviations and perform a timely threat of retaliation. In practice, the concept of historical data primarily relates to the frequency of price (re-) negotiations within the given industry, and can be considered historical if it is several times older than the average length of price re-negotiations (and the relevant contractual relationships). The stability of a given market heavily influences the frequency necessary to facilite collusion: in less stable markets 
with long-term contracts, infrequent exchanges may also be sufficient to have restrictive effects on competition.

Genuinely public information is equally accessible to all competitors and customers, not only in terms of availability but also in terms of its potential costs, and is unlikely to generate a collusive outcome. Practically, genuinely public information is not targeted by market players, in contrast to the data that is available 'in the public domain', but the collecting and processing costs of which deters competitors and consumers from intitiating data collection.

\section{New risk factors and policy challenges in the assessment of information exchange}

Enforcement experiences and challenges summarized by Competition and Market Authority (hereinafter: CMA) reveal that Big Data combined with advanced technologies, such as pricing algorithms, may add new risk factors, if they could have an impact on the markets: (i) by monitoring the prices available on the market and even learning to co-ordinate, an algorithm can introduce parallel behavior, (ii) by being able to identify and segment target groups of consumers who are the most likely buyers of a new entrant and allowing a form of personalized pricing, an algorithm can increase the stability of a market; (iii) by applying the same algorithm and/or the same set of data, the algorithms of the concerned firms may follow the same learning process, which may result also in parallel behaviour (CMA, 2018).

In less concentrated markets, algorithmic pricing can increase the chances of both explicit and tacit collusion, as algorithms are faster than human resources and can collect data from multiple competitors. Thus, price discrepancies can be explored more efficiently, and appropriate counter-strategies can be deployed without delay. Further, pricing algorithms enable companies to adjust their market prices to market changes without human intervention and without any time lag. The increased frequency of market interaction, including price setting, significantly reduces the competitors' willingness to reduce prices as the resulting short-term benefits are minimized. In the long run, the learning process of the algorithms can entirely eliminate price wars as well (CMA, 2018).

It should also be highlighted that the above effects of digitalization in the Big Data age are not limited to online/digital markets. Even the most offline/ traditional markets cannot stay unaffected by the forth industrial revolution and its consequences.

As for the questions arising from Hungarian enforcement practice - although in the end, the problem was not tackled in the decision taken by the Hungarian 
Competition Authority (Gazdasági Versenyhivatalt, hereinafter: GVH) in the Retail Hub-and-Spoke Case ${ }^{10}$ - the arguments presented to the authority also reflected that market structure is heavily influenced by the issue that there are offline/traditional and online/digital segments of the market, and it is not clear to what extent these markets are interconnected and integrated. The online/digital and offline/traditional segmentation of the market was taken into account in several different cases. ${ }^{11}$

Spill-over effects of information made available in social media both directly by firms and indirectly by influencers, whose activity was highlighted by GVH in its Digital Consumer Strategy ${ }^{12}$, may also introduce new aspects for the assessment of risk factors.

Understanding collusion requires a fact-heavy economic assessment, and both Pitruzzella (2017) and Ezrachi and Stucke (2018) point out that increasing concerns of enforcers signal that from a policy perspective the scope of antitrust law should be revised to take into consideration the impacts exposed by the new phenomena of the digitalized economy.

\section{Information exchange in recent Hungarian case law}

\section{The Contact Lenses Case}

\subsection{Assessment of horizontal information exchange}

According to the facts found by the investigation, the four participating companies had a significant market share in the contact lenses and accessories distribution market (hereinafter: contact lenses market), which jointly accounted for $80 \%$ of the relevant market. ${ }^{13}$ The involved market leader participants concluded bilateral agreements with a market research company in 2003, according to which the market researcher was going to conduct an investigation for them with a so-called 'black box' method for more than a decade. In this type of research, market participants provide their own sales data, enabling the independent research company to present the main market trends in an aggregated and properly structured way.

10 Case-VJ-22/2015.

$11 \mathrm{Vj}-89 / 2015, \mathrm{Vj}-103 / 2014$, Final Report on the Online hotel booking sector inquiry retrievable from: http://www.gvh.hu//data/cms1034253/Agazati_vizsgalat_online_szallashelyfoglalas_ piacan_vegleges_jelentes_2016_06_08.pdf (30.07.2019).

12 Középtávú digitális fogyasztóvédelmi stratégia - retrievable from http://www.gvh.hu/data/ cms1039191/GVH_Stategia_Digitalis_fogyved_startegia_2018_09_27.pdf (30.07.2019).

13 Decision of $\overline{G V H ~ V j-96 / 2010 / 310}$ of $13 \bar{J}$ une 2014 . 
The concerned research on the contact lenses market was based on quarterly data collection focused on sales volumes and average prices in different segments and, as a result, the relevant four market participants were presented with reports that included data broken down by companies and product groups. The quarterly reports, which were provided to the participants one and a half months after the given quarter, described market trends for all product types through the aggregated and the individual data on net revenues, quantities and average prices per product and market share. ${ }^{14}$

In its assessment, GVH followed the principles laid down in the Horizontal Guidelines. ${ }^{15}$ As for the market characteristics, GHV stressed that the $80 \%$ joint market coverage of the participants implied a high degree of concentration, which made the market more sensitive to the effects of the information exchange. The contact lenses market can be divided into segments, and there was specialization among the participants to supply some segments. In this way, these market segments could show a higher degree of concentration and be more vulnerable to an information exchange. In this context, GVH emphasized that the sharing of the participants' individual data broken down by segments could have implied a restriction of competition in an oligopolistic market with stable participants, where the number of participants being present in the different product segments was even more limited.

GVH identified a further risk factor, namely that market transparency had been previously low because, also due to the lack of genuine public information, the participants had had no information on their competitors' wholesale prices and sales.

GVH's assessment of the age of the exchanged data reached the conclusion that quarterly price data could not be considered historical data, given that the participants usually made their strategic business decisions (especially on marketing strategy and pricing) on an annual basis. Moreover, pursuant to the Horizontal Guidelines, data become historical only if their age is several times longer than the average length of the contracts in the concerned industry.

Further, market uncertainty can be decreased if the market players can monitor both the impact of some well-observable external market effects (such as competitors' marketing and promotion campaigns, innovation, product range changes) or exogenous shocks, and the competitors' market behavior on their own. At this point, GVH expressed its view that historical datalines for long periods might become also sources of risk: if quarterly data are available for a long period of time, it can be observed how competitors react to certain market situations and shock, and predictions can be made regarding their expected behavior in similar future market events.

14 Decision of GVH Vj-96/2010/310 of 13 June 2014, paras. 72-74.

15 Decision of GVH Vj-96/2010/310 of 13 June 2014, paras. 296-337. 
GVH examined in detail also the nature of the information exchanged, including its strategic nature and level of detail. In this respect, $\mathrm{GVH}$ pointed out, in line with the Horizontal Guidelines, that data on sales and quantities are strategic because it can reduce uncertainty in the market if competitors are aware of these data. The level of detail was of particular importance in the assessment of the case, since data broken down by the individual participant undertakings were made available, and such detailed data were not necessary to follow market trends or identify new market opportunites. For such purposes, aggregated data of the market would have been sufficient, and, on the basis of the aggregated data, the participants could have formed a precise opinion on their market position. It is also important to note that even though the average product prices exchanged in the framework of the market research did not allow calculating particular product prices, this does not diminish the importance of the given information because it can serve as a benchmark in the given segment.

The fact that the participants did not disclose the results of the research in any way to the public was also evaluated; in this way, other market players and consumers could not gain access to the data. Consequently, the use of the research data increased transparency on the upstream side of the market, while consumer-side transparency remained unchanged, which could obviously be detrimental to competition.

On the basis of the data collected during the investigation, GVH attempted to explore the actual market effects of the information exchange and prepared a preliminary market analysis for this purpose. However, the preliminary market analysis did not reveal any behavior that would have clearly been identified as a result of the restrictive effects of the information exchange and that could not have been explained with alternative pro-competitive arguments. Thus, the economic analysis could not lead to clear results, but $\mathrm{GVH}$ considered that even if the actual impact of an information exchange agreement could not be proven, it would still be possible to establish the capability of the conduct to restrict competition (that is, its potiential anticompetitive effect), since the Horizontal Guidelines does not require the proof of restrictive effects on competition. ${ }^{16}$

In general, in the Contact Lenses case GVH did not consider it unlawful to collect and share aggregated market data or to conduct market research. Its decision was focused on the potential restrictive effects of sharing individual company data broken down by market segments in an oligopolistic market with stable participants.

16 Decision of GVH Vj-96/2010/310 of 13 June 2014, paras. 338-341. 


\subsection{Role of the intermediary}

GVH originally planned to establish the market research firm's involvement in the infringement on the basis of the Treuhand-liability principle ${ }^{17}$, which allows the assessment of the joint responsibility of intermediaries involved in a cartel infringement. However, GVH continued to examine two cumulative conditions for establishing Treuhand-liability, that is, the requirements that (i) the intermediary must have contributed to the implementation of the cartel (objective criterion), and (ii) the authority must demonstrate that the intermediary has contributed to the common intention pursued by all the participants and it has been aware of the behavior planned or performed by the other participants to pursue the same objectives, or has reasonably anticipated and was prepared to accept the risk (subjective criterion).

GVH examined the applicability of the Treuhand-liability in relation to a restriction based on potential effect, but came to the conclusion that the objective condition had been unquestionably established. The subjective element could not have been proved by GVH as there was no evidence that the market research company would have organized and conducted its research in the knowledge of the restrictive nature of its behavior.

\subsection{Final decision of the Hungarian Curia}

The decision of GVH in the Contact Lenses Case was subject to judicial review by the Budapest Metropolitan Court. Later, as the court of second instance, the Hungarian Curia terminated the case in its final decision in January $2018^{18}$. In its judgement the Hungarian Curia explained that the evidence on the anti-competitive effects of the participants' conduct were insufficient, that is, GVH had failed to demonstrate any actual anti-competitive effects, while the existence of potential restrictive effects on competition had been merely assumed by the GVH, but had not been proved by supporting evidence satisfying the related legal standards on proofs.

\section{The BankData Case}

\subsection{Another infringement decision based on potential effects}

Following the judgement of the Hungarian Curia in the Contact Lenses Case, the general public is now looking forward to the final outcome of the

17 CFI judgment of 8 July 2008, Case T-99/04 AC Treuhand AG v Commission of the European Communities, ECLI:EU:T:2008:256.

18 Decision of the Hungarian Curia Kfv.II.37.110/2017/13 of 17 January 2018. 
ongoing judicial review in the BankData Case, ${ }^{19}$ since these cases present many similarities. On the one hand, there is a common feature that both cases include long-lasting horizontal information exchange: the Hungarian Banking Association (Magyar Bankszövetség) in collaboration with International Training Centre for Bankers Ltd. (Nemzetközi Bankárképző Központ Zrt.), as joint intermediaries, were operating a database called 'BankAdat' (BankData) for more than a decade (for 12 years). On the other hand, the GVH's assessment in the BankData Case was also based on potentially restrictive effects.

In addition to the above-mentioned intermediaries, the BankData Case involved the members of the Hungarian Banking Association (that is, 33 financial institutions), hence practically the entire Hungarian bank sector was affected by the behavior that was described by GVH as an exchange of private, confidential and strategic information ${ }^{20}$ shared in the database by the members of the Hungarian Banking Association, enabling them to have access to up-todate information about market tendencies and the competitors' strategies and policies. In addition, the participating banks also used the database as a source of input information to set up their strategic and product development plans. In its decision, GVH summarized the factors that entailed high likelihood of a potential restrictive effect (tab. 2$)^{21}$.

GVH attempted to verify the potential impact by a counterfactual analysis, based on an analysis of hypothetical processes that would have taken place in the market without the information access facilitated by the database. However, GVH found that the period preceding the setup of the database was not relevant, since the reformation process of the Hungarian banking system following the transition period was still in progress. For that reason, it could not have served as a proper benchmark. Therefore, it was also considered by the GVH as an option to use the three year period that has elapsed between the termination of the use of the database and the decision of GVH as a benchmark. ${ }^{22}$ In this respect, however, GVH concluded that there had been no long-term data that could have served as a proper basis for the comparison.

19 Decision of GVH Vj-8/2012/1751 of 11 January 2016.

20 The database consisted of 510 data categories, which granted the participants access to data broken down by the counties of Hungary (details of loans and deposits), transactions data, detailed portfolio data for household and corporate loans, details of individual portfolios, staff numbers, detailed breakdown of bank units, number of ATMs and POS terminals - Decision of the GVH Vj-8/2012/1751 of 11 January 2016, paras. 1221, 1251.

21 Decision of GVH Vj-8/2012/1751 of 11 January 2016 - paras. 1204, 1234.

22 The Hungarian Banking Association voluntarily terminated the operation of the database upon the initiation of $\mathrm{GVH}$ proceedings. 
Table 2. Risk factors assessed in the BankData Case

\begin{tabular}{|c|c|c|}
\hline & $\begin{array}{l}\text { Characteristics of the Hungarian bank } \\
\text { sector and risk factors identified in the } \\
\text { investigation }\end{array}$ & $\begin{array}{l}\text { Conclusion regarding } \\
\text { the likelihood of anti- } \\
\text {-competitive collusion }\end{array}$ \\
\hline Structure of the market & $\begin{array}{l}\text { - } \text { moderately concentrated market } \\
\text { - stable market } \\
\text { - } \text { high concentration in some market } \\
\text { segments } \\
\text { - oligopolistic dominant group of } \\
\text { undertakings with a competitive edge }\end{array}$ & high \\
\hline Nature of the products & $\begin{array}{l}\text { - homogeneous products }{ }^{1} \text { and product } \\
\text { range }\end{array}$ & high \\
\hline Dynamics of the market & $\begin{array}{l}\text { - stable demand and supply } \\
\text { - constant conditions of supply }\end{array}$ & high \\
\hline Market players & $\begin{array}{l}\text { - no significant change of market players } \\
\text { - long-term presence in the market } \\
\text { - regular connection between the market } \\
\text { players }\end{array}$ & high \\
\hline $\begin{array}{l}\text { Profit available on the } \\
\text { market }\end{array}$ & - high & high \\
\hline Transparency & $\begin{array}{l}\text { - the participants artificially raised } \\
\text { transparency by the use of the database }\end{array}$ & high \\
\hline Characteristics of data & $\begin{array}{l}\text { - strategic information } \\
\text { - 'key competition parameters' } \\
\text { - business secrets }\end{array}$ & high \\
\hline Market coverage & - large number of participants & high \\
\hline $\begin{array}{l}\text { Aggregated/individual } \\
\text { data }\end{array}$ & - both aggregated and individual data & high \\
\hline Age of data & $\begin{array}{l}\text { - data regarding the previous quarter year } \\
\text { - real-time data }\end{array}$ & high \\
\hline $\begin{array}{l}\text { Frequency of } \\
\text { information exchange }\end{array}$ & $\begin{array}{l}\text { - frequent exchange of data for an } \\
\text { extended period of time }\end{array}$ & high \\
\hline $\begin{array}{l}\text { Public access to } \\
\text { information }\end{array}$ & $\begin{array}{l}\text { - non-public data solely accessible to the } \\
\text { participants }\end{array}$ & high \\
\hline
\end{tabular}

1 The homogeneous nature of financial products was heavily debated in the defense arguments presented by the participants - see paras. $337,599,654,661,675,678,681,687,700,717,726,795$ of Decision of GVH Vj-8/2012/1751 of 11 January 2016.

Source: Decision of GVH Vj-8/2012/1751 of 11 January 2016, paras. 1204, 1234. 
In the summary, GVH emphasized that the potential anti-competitive effect of using the database could be established, since without sharing the information in the database, (i) the strategic uncertainty resulting from the independent behavior of the competitors would have been increased, (ii) the participants would not have been able to build up an accurate picture of the direction and extent of the expansion and target customer base of other market players and they would not have been able to adjust their market behavior to this knowledge, and finally, (iii) the participants would not have been able to stabilize the market structure, and in this way they would not have been able to maintain their market share and profitability throughout the banking market and its two main (that is, household and corporate) segments.

\subsection{Liability of intermediaries}

GVH did not establish the direct liability of the members of the Hungarian Banking Association for the infringement because the authority took the view that the decisions on establishing and operating the database had been taken by the Hungarian Banking Association itself. By holding the association directly liable in this way, the member banks were to bear only subsidiary liability for the enforcement, that is, they might be ordered to pay the fine imposed on the Hungarian Banking Association if such fine could not be collected from the latter. Strategic decisions regarding the database were made by the Hungarian Banking Association but the technical implementation of the information exchange (development of the software; coordination of necessary software updates; provision of hardware and technical background to the operation of the database and the access by the members) was performed by the International Training Centre for Bankers Ltd. as a 'secondary' intermediary, whose direct liability was also established and sanctioned by a fine. ${ }^{23}$

In the BankData Case, GVH established the infringement in relation to the intermediaries on the basis of potential anti-competitive effects, the Treuhand-liability doctrine was expanded when the decision set forth that (i) the interpretation laid down in the AC Treuhand case did not limit the applicability of the intermediaries' liability to by-object hard-core restrictions of competition, and (ii) no conclusion could be drawn from Hungarian caselaw that this type of liability would be excluded in cases assessed on the basis of potential anti-competitive effect. ${ }^{24}$ It is notable that beyond this statement, the decision did not provide any assessment of or even any direct reference

${ }^{23}$ GVH imposed a fine of HUF 15 million (approx. EUR 47 000) on International Training Centre for Bankers Ltd.

${ }^{24}$ Decision of GVH Vj-8/2012/1751 of 11 January 2016, para. 1333. 
to the existence of facts fulfilling the objective and subjective criteria to apply the Treuhand-liability.

\section{The Meat Products RPM Case}

In this case, ${ }^{25}$ the function of the information shared by the market research company was directly linked to the enforcement of a vertical restraint. GVH established a retail price maintenance structure in which a major Hungarian meat product manufacturer used a so-called 'leaflet monitor' market research service to monitor the consumer prices applied by its retail partners.

The software of the 'leaflet monitor' service provides information to market players on the in-scope products (with their photos) currently available in promotional campaigns and the promotional prices on the basis of information published by the retail chains in their consumer leaflets. The leaflet monitor service is a standardized online database from which any manufacturer or wholesaler with access can conduct individual analyses, among others, on the promotional prices and market share of its products.

The leaflet monitor software can be installed by any number of users; data transfer is taking place via e-mails or file-updates, but access is available also directly from the webserver. Users can receive updates on daily product activity in e-mails, which contain the most relevant data for products that are currently in the database. In addition, the market research company regularly produces customized monthly, bi-monthly and quarterly reports and customized reports extracted from the leaflet monitor' database. Reports are available regarding the activity of different brands, products, their comparison, and the advertising activities of competitors. The 'leaflet monitor' software includes also a so-called 'minimum price alert' option, which generates an e-mail warning for the user if some of its products have been advertised by another market player below the given price. ${ }^{26}$

In relation to the 'leaflet monitor' service, $\mathrm{GVH}$ took the view that data subject to the information exchange were based on public information, therefore the behavior of the market research company could not contribute in any unlawful manner to the underlying vertical agreement (that is, the objective criteria of the Treuhand-liability is not satisfied). ${ }^{27}$

25 Decision of GVH Vj-37/2014/303 of 26 July 2016.

${ }^{26}$ Decision of GVH Vj-37/2014/303 of 26 July 2016, paras. 169-179.

27 Decision of GVH Vj-37/2014/303 of 26 July 2016, paras. 441 and 444. 


\section{The Retail Hub-and-Spoke Case}

A hub-and-spoke structure is a specific form of market coordination in which information exchange processes are performed indirectly, through vertical relationships, that is, in such schemes, upstream suppliers or downstream customers may fulfil an intermediary facilitating function. The Retail Hub-and-Spoke Case ${ }^{28}$ was originally launched by GVH to investigate a double hub-and-spoke system but later, in its preliminary position (that is, in a document equivalent to the 'Statement of Objections' used in the proceedings of the European Commission), GVH finally assessed the following 'one-hub' structure:

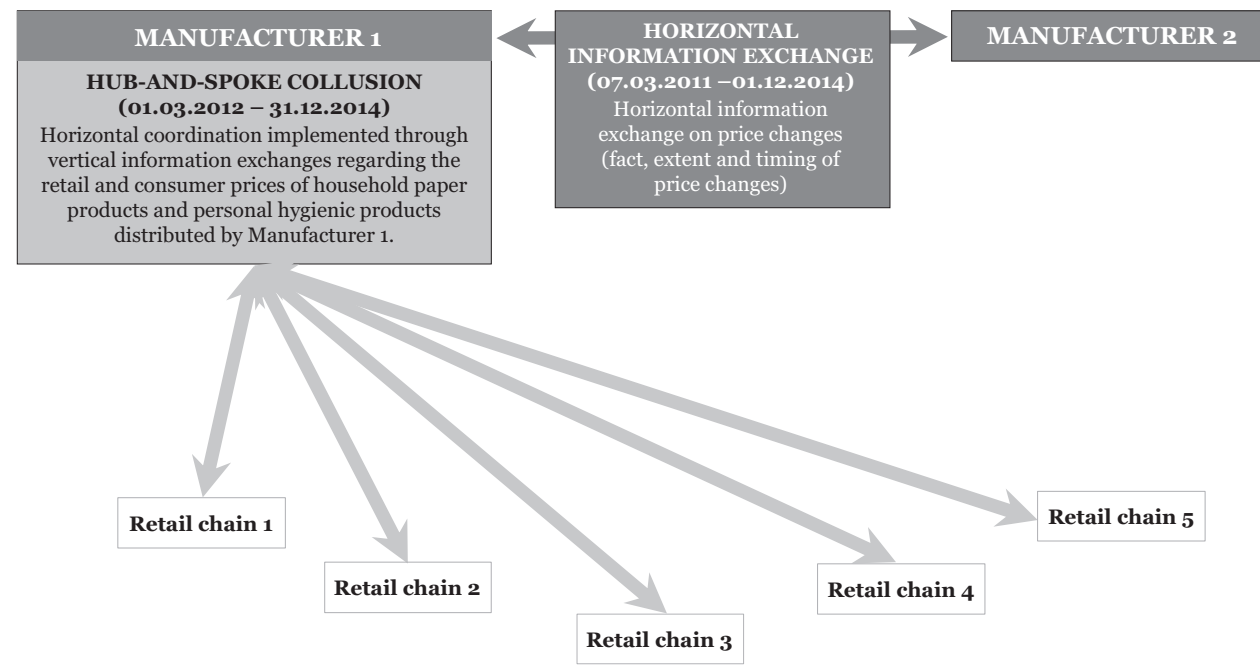

Source: Authors' own work.

$\mathrm{GVH}$ has adopted a decision that considering the indirect information exchange taking place in the hub-and-spoke structure, the infringement, namely the concerted practice resulting in the deliberate elimination of the risks of competition, can be established if the following cumulative criteria are met. Firstly, it must be proved that when the retail chain shared given pieces of information with the manufacturer in their - otherwise legitimate - vertical relationship, the retail chain provided this information with the intention or the presumption that the manufacturer would share it with competing retail chains. Thus, as a first step, the behavioral element (transfer of information to the manufacturer by the retail chain) and the related state of mind require a detailed assessment.

28 Decision of GVH Vj-37/2014/303 of 26 July 2016. 
Secondly, owing to the specific nature of the indirect relationship, it is also necessary to examine when the manufacturer passed competition-sensitive information from one retail chain to another retail chain, whether the latter retail chain knew or at least could recognize the circumstances under which the manufacturer had obtained this information. Thus, as a second step, the examination of another behavior element (that is, transfer of information by the manufacturer to competing retail chains) and the related state of mind (that is, whether the receiving party recognized the circumstances under which the manufacturer could access the concerned information) must be revealed.

These steps are essential to provide sufficient evidence that the retail chains deliberately replaced the risks of competition with the indirect coordination existing between them.

Ultimately, the infringement can be established, if both previously described stages of evidence related to the behavior of the retailers are fulfilled, and, in addition, it must also be demonstrated that in the course of its market conduct, the retail chain applied the information received indirectly, through the manufacturer.

The decision seems to have adopted the assessment framework evolved in British case-law ${ }^{29}$ and applied the intent/state of mind requirement ${ }^{30}$ in a multi-step approach following the route of the information. In the Retail Hub-and-Spoke Case, this approach resulted in the termination of the case because in the light of the evidence available, it could be established in only two separate information exchange situations that the manufacturer had provided competition-sensitive information to one of the retailers on its competitors' planned future price changes. Not even in these two occasions, however, could it be properly proved that the information-providing retailers

29 Case CP/0871/01 Price-Fixing of Replica Football Kit [2003]; Case 1022/1/1/03 JJB Sports plc v Office of Fair Trading [2004] CAT 17; Case 2005/1071, 1074 and 1623 Argos Limited and Littlewoods Limited v Office of Fair Trading and JJB Sports Plc v Office of Fair Trading [2006] EWCA Civ 1318.; Case CP/0480-01 Agreements between Hasbro UK Ltd, Argos Ltd and Littlewoods Ltd Fixing the Price of Hasbro Toys and Games [2003]; Case 1188/1/1/11, Tesco $v$ Office of Fair Trading [2012] CAT 31.

30 Case 2005/1071, 1074 and 1623, Argos Limited and Littlewoods Limited v Office of Fair Trading and JBB Sports plc v Office of Fair Trading [2006] EWCA Civ 1318, para. 141.: 'The proposition which, in our view, $[\ldots]$ is sufficient to dispose of the point in the present appeal can be stated in more restricted terms: if (i) retailer A discloses to supplier B its future pricing intentions in circumstances where A may be taken to intend that B will make use of that information to influence market conditions by passing that information to other retailers (of whom $\mathrm{C}$ is or may be one), (ii) $\mathrm{B}$ does, in fact, pass that information to $\mathrm{C}$ in circumstances where $\mathrm{C}$ may be taken to know the circumstances in which the information was disclosed by A to $\mathrm{B}$ and (iii) $\mathrm{C}$ does, in fact, use the information in determining its own future pricing intentions, then $\mathrm{A}, \mathrm{B}$ and $\mathrm{C}$ are all to be regarded as parties to a concerted practice having as its object the restriction or distortion of competition.' 
had anticipated or could have reasonably foreseen that the manufacturer would pass the information to any of their competitors.

\section{Recent Hungarian experiences: challenges to the enforcement}

Competition law has been modeled on information and decisions processed by the human mind, and also the experiences obtained from some enforcement elements make it clear that the digitalized markets make it inevitable to rethink some issues.

\section{Role of extended economic and IT-related argumentation in the evidence}

The Contact Lenses case has made it clear, and the BankData case also supports the fact, that proving information-sharing is extremely difficult. The examination of information exchange cases is extremely fact-sensitive and requires specific economic argumentation. The assessment of risk factors presented in detail in the Contact Lenses Case has also revealed the essential role of economic analysis and the lack of normative legal criteria for the assessment. GVH has pointed out some of these difficulties, in particular the fact that the economic analysis is mostly performed on data obtained in the investigation, the quality of which is not uniform.

\section{Presence of 'secondary' intermediaries}

The BankData case has raised serious theoretical issues by (i) considering the behavior and decisions of an association of undertakings as an intermediary, (ii) extending the applicability of the Treuhand-liability principle to the assessment of cases based on potential anti-competitive effects. However, there is an additional remarkable strand of the case that comes from the highly specialized role performed by the International Training Centre for Bankers Ltd. in the IT-implementation of the comprehensive information exchange. It seems likely that in the future, an increasing number of cases may occur in which without adequate knowledge and resources in the field of IT, the decision on information exchange cannot be executed directly by the 'primary' intermediary itself. This may increase the complexity of information exchange scenarios, and enforcers may face new difficulties in the assessment of liability (with special regard to the proof on the subjective relation that the secondary 
intermediary actually executing the information exchange might have in regard of the purposes of such information exchange).

Further, in the recent years, new data-based IT-services, for example data mining, have emerged (and some of them have also created new markets) that, by monitoring and sorting large data sets, may supplement the traditional toolset and methodology of market research to identify patterns and outlining future trends. The expansion of data available for analysis and new generations of intermediaries with advanced IT-tools entering the market are recent developments that may intensify the tendencies outlined by Fejes (2016). Finally, a competition law dispute may become a battlefield not only for lawyers but also for economists and IT experts. On the one hand, the uncertainties of proof accompanied by the threat of significant sums of potential fines ${ }^{31}$ can deter market participants from using advanced market focused IT systems, and on the other hand, interdisciplinarity of proof (regarding, for example, complex economic or statistical assessments) may considerably deteriorate the effectiveness of judicial control.

\section{Costs of information exchange}

In the Meat Products RPM Case, GVH stated that the data available through the 'leaflet monitor' service were based on public information, and access was granted to all market players, so the behavior of the market research company could not contribute in any unlawful manner to the underlying vertical agreement. The decision, however, did not clarify if the data shared through the 'leaflet monitor' database could be considered genuinely public information as defined by the Horizontal Guidelines ${ }^{32}$ since the cost dimension of collecting public information and access to the database were not clearly elaborated.

As for the future, a large number of structured and unstructured data that are theoretically publicly available in the online space may add new elements to the assessment of costs involved in collecting and processing public data. Large sets of unstructured data are accumulated in the public domain but since these do not conform to any specific model, they are practically not available to the public without the advanced use of algorithms. The new methods of extracting information valuable to the market and the definition of the cost element of access to public information may also raise questions in investigations, which necessitate economic and IT support in the field of proof.

31 In the BankData case GVH imposed a total fine of HUF 4.015 billion (approx. EUR 12,5 million).

32 Horizontal Guidelines, paras. 92-94. 


\section{Age of the data}

Although the Retail Hub-and-Spoke Case was terminated due to the lack of evidence, and the decision does not contain a detailed description of the relevant market and the investigated behavior, a closer examination of the information flow in the alleged hub-and-spoke structure raises, among others, the question of unilateral price disclosure and age of information in markets where the offline (traditional stores) and online (webshops) segments are interconnected and integrated. Retail of fast moving consumer goods may serve as an example for the markets where the real-time consumer prices of the products are available either in webshops or on price comparison websites or applications, and the dynamics of the market are defined by constantly repeated promotional campaigns and price discounts (that are often also disclosed and advertised in advance), which do not clearly fall in line with the average length of the contracts in the industry and the usual frequency of price negotiations.

The integration of online and offline market segments may ease the coordination because the manual collection of data can be avoided and algorithmic pricing strategies can be expanded to traditional 'brick-and-mortar' segments.

\section{Demand-side initiatives of GVH}

\section{Demand-side effects of digital economy}

The digital era has transformed consumers' lives by introducing new ways of communication and generating new activities that are relevant from an economic and competition law point of view. On the one hand, consumers' traditional roles have been expanded, since they are present on the demand side not only by their purchasing decisions, but they create new content, share information, rank products and discuss their performed or planned consumer choices. On the other hand, there are industries where consumers pay with their personal data for'free'services, and consumers' data serve as the'fuel'of economic growth.

The demand side is undergoing rapid changes. There are many fundamental questions that are still open, among others, it is not quite clear whether algorithms support human decision-making, since the logic and the learning processes of the algorithms differ from the processes of human thinking and learning by necessity. As a result, some experts were led to draw the conclusion that explaining the individual decisions of algorithms in a way 
that is human interpretable might present itself as a significant problem. ${ }^{33}$ Competition authorities are also assisting consumers in not feeling lost if they meet unprecedented situations taking place in the digital marketplaces. The CMA also indicates some demand-side topics for further research, considering potential countermeasures as well: (i) to what extent customers can request secret offers from suppliers in order to undermine collusion; (ii) how consumers can create and use significant buyer power through joint purchasing; (iii) how consumers can mask their data to hide their information to avoid personalized prices (CMA, 2018).

By new types of competition issues, the digital economy raises competition enforcement challenges at different levels also in Hungary. Beyond performing investigations, $\mathrm{GVH}$ also plays an eminent role in the field of competition advocacy and policy making. GVH can draw a full picture of competition since it has competence in both supply-side and demand-side matters. GVH can act as an enforcement center, since it has tasks also in unfair commercial practices matters, provided that the nature and extent of an unfair commercial practice may substiantially affect the competition process by distorting consumers' choices. ${ }^{34}$

\section{Digital Consumer Strategy}

GVH has understood that impacts of digitalization spill over and reshape demand-side behaviour. In recent years, GVH's attention has been focused on unfair commercial practices related to the digital and database-related economy in order to understand what consumer harm may arise if no adequate competition interventions and policies are implemented to govern the new market phenomena.

$\mathrm{GVH}$ has realized that there are persons among consumers who can exercise a dominant influence in the digital environment (influencers), and information disclosure by influencers can take many forms (labelling with hashtags, product placements, sponsored posts, comments, etc.), mostly on

33 Gershgorn, D. (2016) quotes Devi Parikh (Virginia Tech) who serves as a chair for the European Conference on Computer Vision.

34 As regards unfair commercial practices, Act XLVII of 2008 on the Prohibition of Unfair Commercial Practices Against Consumers divides the competences between GVH, the consumer protection authority and the financial supervisory authority. The latter two act in cases where the concerned commercial practices are not supposed to substantially affect competition. Significant impact on competition process is presumed, among others, if the commercial practice is performed through a media service provider offering nationwide media service or through periodicals or below-the-line promotional activities available at least in three of the 19 counties of Hungary. 
some platforms of social media. In 2017, GVH published a guidance document outlining the requirements on influencer activities sponsored by advertisers. ${ }^{35}$ Interconnection between data protection law and competition law has also emerged in the Hungarian case-law, where provision of misleading information about the management of consumers' personal data was sanctioned.

$\mathrm{GVH}$ has adopted the approach that

'The dynamics of digital markets, the special features of the demand and supply side, and in particular the unique characteristics of the consumers' decisions, which differ from other markets, necessitate the application of new tools and the establishment of priorities for the future. ${ }^{36}$

In 2018, GVH continued its proactive policy-making to ensure that the same standards apply to consumer decisions taken both in online/digitalized and offline/traditional markets, and therefore launched a Digital Consumer Strategy in which it summarized the experiences collected and set priorities to optimally allocate its resources.

Tools allowing consumers to compare prices are essential in consumers' orientation in the digital marketplace. It is an additional question if these tools should also offer masking features to hide consumer information and/or provide a benchmark for prices calculated on the basis of clean/anonymised consumer profiles.

Recently, in March of 2019, GVH launched a market analysis in order to understand the application of digital comparison tools (available websites and mobile-applications) and their effects on consumer decision-making process. ${ }^{37}$ GVH emphasizes that on the one hand, these comparison tools can improve the information environment of consumer decision and, at the same time, increase transparency, but they can meet these goals if they can generate appropriate information as an input to consumer decisions. The market analysis was targeted on sectors where (i) consumers meet high search costs; (ii) comparison tools are widely used; (iii) a limited number of comparison tools is available and/or (iv) price comparison is accompanied by intensive

35 Hungarian Competition Authority (2017). \#GVH\#Compliance\#Influencer. Retrieved from: http://www.gvh.hu/en/data/cms1037361/aktualis_hirek_gvh_megfeleles_velemenyvezer_ 2017_11_30_a.pdf (30.07.20190).

${ }^{36}$ Hungarian Competition Authority (2017). Press Release:Results and new directions in consumer protection - the digital strategy of the GVH has been published. Retrieved from: http:// www.gvh.hu/en/press_room/press_releases/press_releases_2018/results_and_new_directions_in_ consumer_protection.html (30.07.2019).

37 Hungarian Competition Authority (2019). Press Release: The GVH will assess the operation of digital comparison tools in the framework of a market analysis. Retrieved from: http://www. gvh.hu/en/press_room/press_releases/press_releases_2019/the_gvh_will_assess_the_operation_ of_digital_compa.html (30.07.2019). 
additional communication. On the basis of these aspects, retail, reservation of accomodation, travel services, financial and insurance services were identified as markets comprising the primary scope.

\section{Conclusions}

The aim of this article was to highlight the impact of the fourth industrial revolution on markets through introducing how digitalization and even traditional industries going online can affect information exchange. The assessment of information exchange as a potential - 'by object' or 'by effect' - restraint on competition is highly influenced by market characteristics. The main characteristics facilitating a collusive outcome are summarized in the table presenting market characteristics of the BankData case.

The availability of strategic information in abundance - provided by the Big Data environment - and the development of highly efficient processing methods enables a higher level and a different kind of information exchange superior to past conducts.

Although the very fast and exponential growth of digitalization has already influenced the information exchange practice of competition authorities - as it is presented above through the recent case-law of GVH - the real outbreak of digitalization and Artificial Intelligence still remains to be seen.

As it is presented by introducing the basic model of the Prisoner's Dilemma, collusion in traditional market settings is an unstable outcome. The higher the number of firms involved, the more difficult the environment to collude in traditional industries is. The use of algorithms could facilitate collusion by allowing coordination and monitoring of a larger number of firms. The increasing availability of online data jointly with algorithms is very likely to enhance both transparency in the market and the frequency of interactions, which make industries more prone to collusion. It is highly questionable, however, that the availability of online data itself would be the only key component of the new risks for competition. The increase of market transparency results at least to the same extent from modern data mining technologies and the ability of algorithms to make predictions and to reduce strategic uncertainty. The increase of market transparency is not only a result of more data being available: complex algorithms with powerful data mining capacity provide an excellent tool to distinguish between intentional deviations from collusion and natural reactions to changes in market conditions (Claici, 2018).

We should not forget that cooperative outcome provides a higher return to firms, so replacing competition with coordination might be a rational way 
to maximize profits. And since it is rational for humans, it will be rational for algorithms. As Ada Lovelace expressed: 'The Analytical Engine has no pretensions whatever to originate any thing [...] It can do whatever we know how to order it to perform. ${ }^{38}$

The future can lead even further as Ezrachi and Stucke (2018) highlights, however, at the moment, competition law - and enforcers - should be ready to face the current challenges of digitalization, Big Data and algorithms.

\section{Literature}

Belényesi, P. (2016). Digitális Platformok és a Big Data. Verseny és szabályozás, 2016. Retrieved from http://econ.core.hu/file/download/vesz2016/bigdata.pdf (30.07.2019). Capobianco, A. and Nyeso, A. (2018). Challenges for Competition Law Enforcement and Policy in the Digital Economy. Journal of European Competition Law \& Practice, 1, p. 19-27, http://dx.doi.org/10.1093/jeclap/lpx082 (30.07.2019).

Claici, A. (2018). Big Data and Competition Policy. FUNCAS Social and Economic Studies, 5 (Economic Analysis of the Digital Revolution).

CMA (2018). Pricing algorthms - Economic working paper on the use of algorithms to facilitate collusion and personalised pricing. Retrieved from https://assets.publishing. service.gov.uk/government/uploads/system/uploads/attachment_data/file/746353/ Algorithms_econ_report.pdf

Ezrachi, A. (2018). EU Competition Law Goals and the Digital Economy. Oxford Legal Studies Research Paper, 17. Retrieved from: (30.07.2019). https://papers.ssrn.com/sol3/ papers.cfm?abstract_id $=3191766$

Ezrachi, A. and Stucke, M.E. (2016). Virtual Competition: The Promise and Perils of the Algorithm-Driven Economy, Harvard University Press.

Ezrachi, A. and Stucke, M.E. (2018). Sustainable and Unchallenged Algorithmic Tacit Collusion. Retrieved from: https:/www.academia.edu/37782974/Sustainable_and_ Unchallenged_Algorithmic_Tacit_Collusion (30.07.2019).

Fejes, G. (2016). Az információcsere és a közvetítő - avagy régiségek és újdonságok a kartelljog területéről. Versenytükör, 4, p. 40-50.

GVH (2018). Középtávú digitális fogyasztóvédelmi stratégia. Retrieved from: http://www. gvh.hu/data/cms1039191/GVH_Stategia_Digitalis_fogyved_startegia_2018_09_27.pdf (30.07.2019).

Gershgorn, D. (2016). We don't understand how AI make most decisions, now algorithms are explaining themselves. Retrieved from: https://qz.com/865357/we-dont-understand-howai-make-most-decisions-so-now-algorithms-are-explaining-themselves/ (30.07.2019).

ICO (2017). Big data, artificial intelligence, machine learning and data protection. Retrieved from: https://ico.org.uk/media/for-organisations/documents/2013559/big-data-ai-ml-anddata-protection.pdf (30.07.2019).

38 Quotation from the author of the first computer program. (Isaacson, 2014). 
Isaacson, W. (2014). Innovators: How a Group of Hackers, Geniuses, and Geeks Created the Digital Revolution. Simon \& Schuster.

Ivaldi, M., Jullien, B., Rey, P., Seabright, P. and Tirole, J. (2003) The Economics of Tacit Collusion. Final Report for DG Competition, European Commission. Retrieved from http://ec.europa.eu/competition/mergers/studies_reports/the_economics_of_tacit_ collusion_en.pdf (30.07.2019).

Lasserre, B. and Mundt, A. (2017). Competition Law and Big Data. The Enforcers' View. Rivista Italiana di Antitrust, 1, 86-103, DOI: 10.12870/iar-12607

Maier, N. (2018). Az adat mint termék a versenyjogban. Verseny és szabályozás, 2018. Retrieved from: https:/www.mtakti.hu/wp-content/uploads/2019/03/Vesz2018_03_ MaierN_adat.pdf (30.07.2019).

Morris, J.W. . (2015). Curation by code: Infomediaries and the data mining of taste. European Journal of Cultural Studies, 18. 446-463. DOI: 10.1177/1367549415577387.

Nicholson, W. and C. (2010) Snyder Intermediate Microeconomics and its Application. 11th Edition. Cengage Learning.

OECD (2017). Algorithms and Collusion: Policy in the Digital Age. Retrieved from: http:// www.oecd.org/daf/competition/Algorithms-and-colllusion-competition-policy-in-thedigital-age.pdf (30.07.2019).

Pitruzzella, G. (2017). Big Data and Antitrust Enforcement. Rivista Italiana di Antitrust, 1, 77-86. DOI: 10.12870/iar-12609.

Preta, A. and Maggiolino, M. (eds.) (2018). Data Driven Economy: Market Trends and Policy Perspectives. Retrieved from: http://www.itmedia-consulting.com/DOCUMENTI/ datadrivensummary.pdf (30.07.2019).

Rosenfield, A.M., Carlton, D.W. and Gertner, R.H. (1997) Communication among Competitors: Game Theory and Antitrust Application of Game Theory to Antitrust. 5 George Mason Law Review 423

Simon, B. (2012). A koordinatív hatások megjelenése a magyar joggyakorlatban. Versenytükör. 2. 22-30.

Thiel, P. and Masters, B. (2014). Zero to One: Notes on Startups, or How to Build the Future. The Crown Publishing Group.

Tóth, A. (2018). Algoritmusok és versenyjog. Versenytükör, 2, p. 40-50. 